\title{
Water-Nutrient-Food Nexus: The Role of Green Algae for Sustainable Food Production in Urban Wetlands Through Untreated Wastewater
}

\author{
Hussnain Mukhtar ${ }^{\#}$ and Muhammad Imran ${ }^{\#}$ \\ \# Environmental Engineering and management, Asian Institute of Technology, Pathumthani, Bangkok, 12120, Thailand \\ E-mail: agricultureenvironment33@gmail.com
}

\begin{abstract}
The nutrients in domestic wastewater are increasingly being regarded as a valuable resource for energy and nutrient recovery for an Eco-city. The nutrient stream can be used safely for food production through ecological engineering interventions (introduction of green algae in urban wetlands). Effects of wastewater on growth yield and microbial contamination on hydroponic tomato (Lycopersicon esculentum) was studied in pilot scale wetland for 6 month under the presence of green algae (Euglena sp.) with different chlorophyll $a$ concentration. Domestic wastewater (BOD 205 mg. $\mathrm{L}^{-1}$, TN $29 \mathrm{mg.L} \mathrm{L}^{-1}$ and TP 8 mg.L $\mathrm{L}^{-1}$ ) with loading rate of 0.9 $L . \mathrm{m}^{-2} . \mathrm{d}^{-1}$ was used for each wetland. The wastewater did not affect fruit $\mathrm{pH}$, increased their size up to $1.7 \pm 0.31 \mathrm{~cm}$ in diameter, and weight up to $69.3 \pm 6.0 \mathrm{~g}$. Microbial contamination (Total coliforms (TC) and Fecal coliforms (FC)) on fruit surface significantly decreased $\left(p<0.05\right.$ ) with the increasing algal concentration up to $240 \mu \mathrm{g} . \mathrm{L}^{-1}$. Inactivation of bacterial contamination (TC and FC) under the presence of algae associated with high dissolved oxygen concentration $\left(9.7 \pm 1.1 \mathrm{mg} . \mathrm{L}^{-1}\right)$ and $\mathrm{pH}$ increases $(8.2 \pm 0.8)$ attributes in wetland. In summary, tomato production in urban wetlands under the presence of green algae enhances the importance of safe and sustainable food production through untreated wastewater.
\end{abstract}

Keywords - Sustainable; Food; Wastewater; Algae; pathogens.

\section{INTRODUCTION}

Agriculture has been carried out in several types of wetlands for millennia, with crop fields on river floodplain soils and rice fields as major examples [1]. Urban wetlands provide the sustainable way for food production through nutrient recycling but expansion and intensification of agriculture for food production alter the patterns of resource availability in ecosystems [2]. New urban development required ecological balanced system for food production by minimize land use and enabling resource recycling [3].The direct use of recovered wastewater for food production in cities can also improve the efficiency of nutrient recycling and water use - especially important in countries with limited water resources [4]. There is also sustainable opportunity is the growing of food in urban area using hydroponic and nutrients recovered from wastewater stream and recycling of carbon. Wastewater reuse for agriculture production in wetlands is associated with some health risks due to the possibility of the presence of a wide spectrum of pathogens, such as, coliform bacteria, hence, contaminated water or wastewater has a great potential for transmitting a wide variety of diseases and illnesses [5]. However, irrigation with wastewater that highly polluted with coliforms, fecal coliforms, and other bacteria may increase the contamination of vegetables, but the contamination could be minimized by well managed practices [6]. In this regards, Algae play a vital role in removal of pathogens in water bodies [7]. The presence of microalgae in the wetlands was found to play a significant role in inactivation of coliforms (TC and FC), which may have some beneficial consequence with a view to water quality enhancement Inactivation of $E$. coli through algae is the combination of different factors in which increasing $\mathrm{pH}$ and dissolve oxygen are the key parameters [8]. A pH variation above than 8 or less than 4 are effective in pathogens removal action [9], where fluctuations in $\mathrm{pH}$ value also reduce the chance of survival of faecal bacteria [10]. The inactivation mechanism of total coliforms (TC) and fecal coliforms (FC) by DO is primary due to the $\mathrm{OH}$ radical [11]. This implies that the approximate potential of $\mathrm{OH}$ radical for $2 \log$ inactivation of $E$. coli is thousand times as effective as other common disinfectants. [11], [12]. This study aims to under-score the potential of wastewater nutrient recycling in wetlands with a view to sustainable Food supplies to urban cities.

\section{MATERIALS AND METHOD}

\section{A. Green algae and hydroponic tomato introduction}

The artificial floating island system was used for tomato production, which was set up using foams and wooden 
structure. The experiment was conducted in three sets of free surface wetlands $(n=3)$ with surface area of $10.6 \mathrm{~m}^{2}$ respectively, where depth varies from 1 to $1.1 \mathrm{~m}$. Domestic wastewater (BOD $201 \mathrm{mg} . \mathrm{L}^{-1}$, TN $28 \mathrm{mg} . \mathrm{L}^{-1}$ and TP $9 \mathrm{mg} . \mathrm{L}^{-}$ $\left.{ }^{1}\right)$ with loading rate of $1.2 \mathrm{~L} \cdot \mathrm{m}^{-2} \cdot \mathrm{d}^{-1}$ was used for each wetland. Culture of pure algal species (Euglena sp.) was grown with nutrient solution (Nitrogen $10.8 \mathrm{mg} . \mathrm{L}^{-1}$ and Phosphorus $2.1 \mathrm{mg} . \mathrm{L}^{-1}$ ) under the sun light. Algae were harvested after 18 days of inoculation. Centrifugation (2000RPM, $15 \mathrm{~min}$ ) was used to obtain thick algae layer which was diluted with distilled water to obtain required chlorophyll $a$ concentrations. The range of chlorophyll a concentration used for pathogen inactivation varies from 50 to $550 \mu \mathrm{g} . \mathrm{L}^{-1}$.

\section{B. Tomato fruit quality examination}

Tomato fruits were hand harvested at an advanced full red stage of maturity (vine-ripe). Fruit colour was evaluated by using colour chart to conform that fruit was at its maturity level [13]. pH was determined in tomato fruit extract with Milwaukee MW102 meter. Fruit size was determined by measuring the diameter of fruit at maximum circumference with the help of caliper, where fruit weight was determined with an auto balance (Model "Cubis-MSA524P-000-DA").

\section{Microbial examination}

Harvested tomato fruits were washed with tap water, under laminar air-flow hood. Fruit skin was removed and sterilized mixer was used to mix thoroughly in water. The same procedure was repeated for fruit flesh. Samples from the three parts were used for coliform testing using multipletube fermentation technique [14] . For water quality analysis, sample was collected in sterilised glass bottles from two points in wetlands. Ten percent of sodium thiosulfate $\left(\mathrm{Na}_{2} \mathrm{~S}_{2} \mathrm{O}_{3}\right)$ was added to the samples that have been treated with chlorine, as a de-chlorinating agent to neutralise any residual chlorine and to prevent continuation of its action on bacteria thereafter. Total coliform and fecal coliform in water and wastewater is determined by using multiple-tube fermentation technique and spread plate method [15]. Chlorophyll a was determined spectrophotometrically [16] after filtration on Whatman GF-C glass filters and $24 \mathrm{~h}$ extraction in $90 \%$ acetone. Water samples were collected weekly for 6 months from three wetlands to determine the effect of macrophyte on rotifer concentration and their effect on microbial level in pilot scale wetland and on fruit surface and flesh.

\section{RESULT AND DISCUSSION}

\section{A. Tomato fruit $\mathrm{pH}$}

Table 1 shows that fruit $\mathrm{pH}$ was not affected. The results of the tomato fruit $\mathrm{pH}$ values obtained were always within the range of 4 , typical to tomato fruit.

\section{B. Tomato weight and size}

Fruit diameter was affected by different chlorophyll $a$ concentration (Table 1). Data showed a significant increase in fruit diameter by the use of less concentration of chlorophyll $a$ (as tomato plant gets more nutrients due to less algal growth). The highest value was obtained for $0 \mu \mathrm{g} / \mathrm{L}$, where $350 \mu \mathrm{g} . \mathrm{L}^{-1}$ the lowest fruit diameter (Table 1). The increase in diameter was following the order of: $350 \mu \mathrm{g} . \mathrm{L}^{-1}<$ $250 \mu \mathrm{g} . \mathrm{L}^{-1}<150 \mu \mathrm{g} . \mathrm{L}^{-1}<0 \mu \mathrm{g} . \mathrm{L}^{-1}$ (Table 1).The similar results were obtained for weight of tomato fruit. These results can be explained under the umbrella of nutrient availability to tomato plants. As chlorophyll concentration increase in wetland, a great part of nutrient seeped through wastewater was used by algae which effect on tomato growth (size and Weight).

TABLE I

QUALITY PARAMETERS OF HARVESTED TOMATO FRUIT

\begin{tabular}{|l|l|l|l|}
\hline Treatment & \multicolumn{3}{|c|}{ Parameters } \\
\hline Chlorophyll $\boldsymbol{a}(\boldsymbol{\mu g} / \mathbf{L})$ & Size $(\mathbf{c m})$ & Weight $(\mathbf{g})$ & Ph \\
\hline 0 & $2.4^{\mathrm{a}}$ & 81.3 & 4.7 \\
\hline $50 \pm 4$ & 2.3 & 79.9 & 4.5 \\
\hline $150 \pm 7$ & 2.3 & 78.1 & 4.5 \\
\hline $250 \pm 12$ & 2.2 & 75.5 & 4.3 \\
\hline $350 \pm 21$ & 2.2 & 73.6 & 4.1 \\
\hline
\end{tabular}

a Means are the average of 25 fruit.

\section{Total coliform (TC) and Fecal coliform $(F C)$ elimination through Algal growth}

Algal were found to play a significant role in reduction of TC and FC through enhancement of rotifer concentration. The rate of TC and FC inactivation increase with increasing rate of chlorophyll $a$ concentration. Algae increase DO level in water and produce free radical $\left(\mathrm{OH}, \mathrm{H}_{2} \mathrm{O}_{2}\right)$, which plays a vital role in inactivate of TC and FC [17]. DO concentrations more than $0.5 \mathrm{mg} / \mathrm{L}$ have considerable effect on total coliforms (TC) and fecal coliforms (FC) inactivation. The inactivation mechanism of TC and FC by DO is primary due to the $\mathrm{OH}$ radical which is approximately thousand times more effective as compare to other disinfectant.

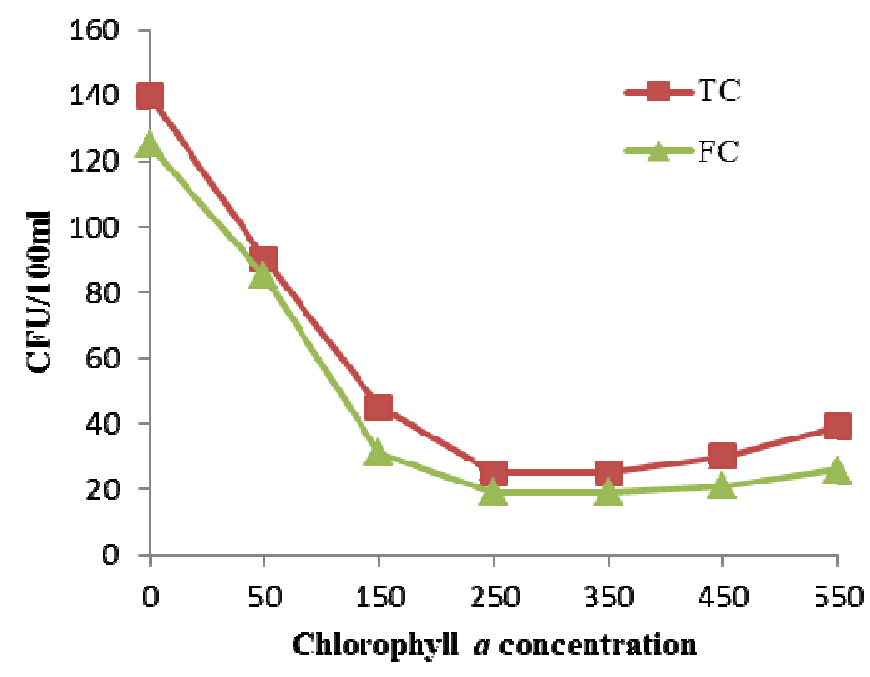

Fig. 1 Microbial contamaination (TC and FC) in wetland in regards to Chlorophyll $a$ concentration

It is reported that the release of algal organic matter as a result of algal cell lysis can enhance coliform survival and even growth [18], [19]. It is therefore expected that at high chlorophyll a concentrations, algal cell lysis will lead to significant reduction in DO and hence results to low total 
coliforms (TC) and fecal coliforms (FC) die-off rate. Figure shows that total coliforms (TC) and fecal coliforms (FC) die off rate increase until chlorophyll a value approaches to $250 \mu \mathrm{g} . \mathrm{L}^{-1}$, which describe that total coliforms (TC) and fecal coliforms (FC) die off rate can be disturb by presence of algal organic material. Hence this proved that low concentration of algal in water bodies have beneficial consequence on TC AND FC removal rate.

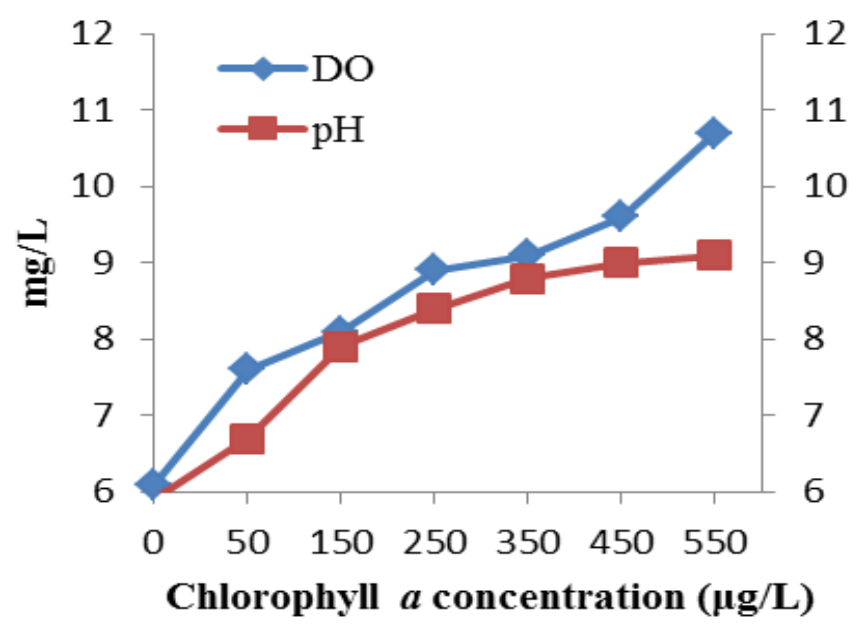

Fig. 2 DO (Dissolve Oxygen) and $\mathrm{pH}$ variation with chlorophyll $a$ concentration.

\section{Microbial contamination on tomato fruit}

Tomato is one of the fresh fruit vegetables that are eaten either raw or cooked. The Institution for Standards and Metrology declared that treated wastewater must not be used to irrigate vegetables that are eaten raw [15]. Cooked vegetables can be irrigated with such water, with maximum range for total fecal coliform count of $1000 \mathrm{CFU} / 100 \mathrm{ml}$ in treated wastewater samples, which is also in accordance with the WHO recommendation [18]. Table 3 shows the concentration of the microbial contamination with TC and FC two parts of tomato fruit (skin and flesh) grown by untreated wastewater with different proportions of algal concentration. Results showed that tomato fruit flesh was completely uncontaminated, whereas tomato fruit skin was the most contaminated as compared to the flesh. Tomato fruit production with chlorophyll a concentration of 250 has the low average contamination of contamination (TC 3 $\mathrm{CFU} / 100 \mathrm{~g}$ and FC $1 \mathrm{CFU} / 100 \mathrm{~g}$, respectively) as compare to 0 (TC $21 \mathrm{CFU} / 100 \mathrm{~g}$ and FC $15 \mathrm{CFU} / 100 \mathrm{~g}$, respectively). This could be attributed to the contamination from direct contact with contaminated irrigation water. Microbial contamination (total coliforms (TC) and fecal coliforms (FC)) on fruit surface significantly decreased $(\mathrm{p}<0.05)$ with the increasing algal concentration up to $240 \mu \mathrm{g} \cdot \mathrm{L}^{-1}$.
TABLE II

Microbiological EXAMINATION, TC AND FC ON TOMATO Fruit PARTS (SKIN AND FLESH) UNDER DIFFERENT CONCENTRATION OF ALGAL CONCENTRATION

\begin{tabular}{|c|c|c|c|}
\hline \multirow{2}{*}{$\begin{array}{c}\text { Treatment } \\
\text { Chlorophyll } a \\
(\mu \mathrm{g} / \mathrm{L})\end{array}$} & \multirow{2}{*}{$\begin{array}{l}\text { Microbial test }^{\text {a }} \\
(\text { CFU/100mL) }\end{array}$} & \multicolumn{2}{|c|}{ Fruit part } \\
\hline & & Skin & Flesh \\
\hline \multirow{2}{*}{0} & TC & 21 & 0 \\
\hline & $\mathrm{FC}$ & 15 & 0 \\
\hline \multirow{2}{*}{50} & TC & 16 & 0 \\
\hline & $\mathrm{FC}$ & 9 & 0 \\
\hline \multirow{2}{*}{150} & $\mathrm{TC}$ & 7 & 0 \\
\hline & $\mathrm{FC}$ & 6 & 0 \\
\hline \multirow{2}{*}{250} & $\mathrm{TC}$ & 3 & 0 \\
\hline & $\mathrm{FC}$ & 1 & 0 \\
\hline \multirow{2}{*}{350} & $\mathrm{TC}$ & 6 & 0 \\
\hline & $\mathrm{FC}$ & 4 & 0 \\
\hline
\end{tabular}

\section{CONCLUSIONS}

Urban wetlands provide the sustainable way for food production through nutrient recycling, where contamination level can be reduced through introduction of algae. Microbial contamination (total coliforms (TC) and fecal coliforms (FC)) on fruit surface significantly decreased ( $\mathrm{p}<$ 0.05 ) with the increasing algal concentration up to $240 \mu \mathrm{g} / \mathrm{L}$, which enhance their importance in line with water quality improvement and health risk mitigation in urban wetlands.

\section{ACKNOWLEDGMENT}

The author wish to acknowledge the financial support from Asian Institute of Technology, Thailand.

\section{REFERENCES}

[1] J. T. A. Verhoeven and T. L. Setter, "Agricultural use of wetlands: opportunities and limitations," Ann. Bot., p. mcp172, 2009.

[2] P. A. Matson, W. J. Parton, A. G. Power, and M. J. Swift, "Agricultural intensification and ecosystem properties," Science (80. )., vol. 277, no. 5325, pp. 504-509, 1997.

[3] W. Mo and Q. Zhang, "Energy-nutrients-water nexus: integrated resource recovery in municipal wastewater treatment plants," J. Environ. Manage., vol. 127, pp. 255-267, 2013.

[4] T. Deelstra and H. Girardet, "Urban agriculture and sustainable cities," Bakk. N., Dubbeling M., Gündel S., Sabel-Koshella U., Zeeuw H. Grow. cities, Grow. food. Urban Agric. policy agenda. Feldafing, Ger. Zentralstelle für Ernährung und Landwirtschaft, pp. 43-66, 2000.

[5] G. A. Al-Nakshabandi, M. M. Saqqar, M. R. Shatanawi, M. Fayyad, and H. Al-Horani, "Some environmental problems associated with the use of treated wastewater for irrigation in Jordan," Agric. Water Manag., vol. 34, no. 1, pp. 81-94, 1997.

[6] R. Armon, C. Dosoretz, Y. Azov, and G. Shelef, "Residual contamination of crops irrigated with effluent of different qualities: a field study," Water Sci. Technol., vol. 30, no. 9, pp. 239-248, 1994.

[7] E. D. O. Ansa, H. J. Lubberding, J. A. Ampofo, and H. J. Gijzen, "The role of algae in the removal of Escherichia coli in a tropical eutrophic lake," Ecol. Eng., vol. 37, no. 2, pp. 317-324, 2011.

[8] R. J. Davies-Colley, A. M. Donnison, D. J. Speed, C. M. Ross, and J. W. al Nagels, "Inactivation of faecal indicator micro-organisms in waste stabilisation ponds: interactions of environmental factors with sunlight," Water Res., vol. 33, no. 5, pp. 1220-1230, 1999.

[9] N. M. Parhad and N. U. Rao, "Effect of $\mathrm{pH}$ on survival of Escherichia coli,” J. (Water Pollut. Control Fed., pp. 980-986, 1974.

[10] E. Awuah, Pathogen removal mechanisms in macrophyte and algal waste stabilization ponds. Taylor \& Francis, 2006.

[11] M. Cho, H. Chung, W. Choi, and J. Yoon, "Linear correlation between inactivation of $\mathrm{E}$. coli and $\mathrm{OH}$ radical concentration in $\mathrm{TiO}$ 
2 photocatalytic disinfection," Water Res., vol. 38, no. 4, pp. 10691077, 2004.

[12] N. K. Hunt and B. J. Mariñas, "Kinetics of Escherichia coli inactivation with ozone," Water Res., vol. 31, no. 6, pp. 1355-1362, 1997.

[13] O. Al-Lahham, N. M. El Assi, and M. Fayyad, "Impact of treated wastewater irrigation on quality attributes and contamination of tomato fruit," Agric. Water Manag., vol. 61, no. 1, pp. 51-62, 2003.

[14] P. Gaspard and J. Schwartzbrod, "Determination of the parasitic contamination of irrigated vegetables," Water Sci. Technol., vol. 27, no. 7-8, pp. 295-302, 1993.

[15] E. W. Rice, L. Bridgewater, and A. P. H. Association, Standard methods for the examination of water and wastewater. American Public Health Association Washington, DC, 2012.
[16] W. E. Federation and A. P. H. Association, "Standard methods for the examination of water and wastewater," Am. Public Heal. Assoc. Washington, DC, USA, 2005.

[17] T. P. Curtis, D. D. Mara, and S. A. Silva, "Influence of pH, oxygen, and humic substances on ability of sunlight to damage fecal coliforms in waste stabilization pond water," Appl. Environ. Microbiol., vol. 58, no. 4, pp. 1335-1343, 1992.

[18] R. Lake and S. Driver, "The role of algae in causing coliform problems within the distribution system," Water Supply, vol. 2, no. 4 pp. 105-110, 2002.

[19] C. Bouteleux, S. Saby, D. Tozza, J. Cavard, V. Lahoussine, P. Hartemann, and L. Mathieu, "Escherichia coli behavior in the presence of organic matter released by algae exposed to water treatment chemicals," Appl. Environ. Microbiol., vol. 71, no. 2, pp. 734-740, 2005. 